\title{
Labour market prospects for occupations and academic studies in 1992
}

Citation for published version (APA):

de Grip, A., Heijke, J. A. M., Dekker, R., \& Groot, L. F. M. (1987). Labour market prospects for occupations and academic studies in 1992. Researchcentrum voor Onderwijs en Arbeidsmarkt, Faculteit der Economische Wetenschappen. ROA Working Papers No. 1E https://doi.org/10.26481/umarow.198701E

Document status and date:

Published: 01/01/1987

DOI:

10.26481/umarow.198701E

Document Version:

Publisher's PDF, also known as Version of record

\section{Please check the document version of this publication:}

- A submitted manuscript is the version of the article upon submission and before peer-review. There can be important differences between the submitted version and the official published version of record.

People interested in the research are advised to contact the author for the final version of the publication, or visit the DOI to the publisher's website.

- The final author version and the galley proof are versions of the publication after peer review.

- The final published version features the final layout of the paper including the volume, issue and page numbers.

Link to publication

\footnotetext{
General rights rights.

- You may freely distribute the URL identifying the publication in the public portal. please follow below link for the End User Agreement:

www.umlib.nl/taverne-license

Take down policy

If you believe that this document breaches copyright please contact us at:

repository@maastrichtuniversity.nl

providing details and we will investigate your claim.
}

Copyright and moral rights for the publications made accessible in the public portal are retained by the authors and/or other copyright owners and it is a condition of accessing publications that users recognise and abide by the legal requirements associated with these

- Users may download and print one copy of any publication from the public portal for the purpose of private study or research.

- You may not further distribute the material or use it for any profit-making activity or commercial gain

If the publication is distributed under the terms of Article $25 \mathrm{fa}$ of the Dutch Copyright Act, indicated by the "Taverne" license above, 


\section{LABOUR MARKET PROSPECTS FOR OCCUPATIONS AND ACADEMIC STUDIES IN 1992}

ROA-W-1987/1E

A. de Grip, J.A.M. Heijke, R.J.P.Dekker, L.F.M.Groot

RESEARCH CENTRE FOR EDUCATION AND LABOUR MARKET

Faculty of Economic Sciences

Rijksuniversiteit Limburg

Maasiricht, December 1987 



\section{ACKNOWLEDGEMENT}

The investigation reported on here has been carried out as part of a long-range research commission of the Dutch Ministry of Education and Sciences concerning the development of an information system of the educational labour market designed to assist students of secondary and higher education in their educational and vocational choices (ROA 1987). The research has been helped along by a supporting assignment in the framework of the I-SEE project, which the "Centrum voor Beleidsanalyse en Advies" (Centre for Policy Analysis and Consultation" in Nijmegen is carrying out for the "Interdepartementale Stuurgroep Studie- en Beroepskeuze Voorlichting" (Interdepartmental Advisory Committee for Educational and Vocational Choices). The I-SEE-project (Information System on Education and Employment) envisages the development of an automated system for educational and vocational choice. It is to be a system composed of several modules, and our Research Centre has produced data needed to construct the so-called labour-market module (De Grip, Heijke, Dekker, Groot and Vos 1987).

The present working paper should be regarded as the first version of a still incomplete information system for the educational labour market. We were able to develop it quickly by applying relatively simple quantitative (forecasting) methods to instantly usable basic information, and wherever possible making use of forecasts already made by others. For a more sophisticated system, the statistical base and the methods need to be improved and extended, and data from forecasts for segments of the labour market utilised.

The research was directed by Professor J.A.M. Heijke, director of the Research Centre. The day-to-day management was entrusted to Dr. A. de Grip. R.J.P. Dekker and L.F.M. Groot gave their valued assistance, L.A. Vos helped to process the data material. 


\section{CONTENTS}

page

1. Introduction 3

2. Employment forcast 8

2.1 Introduction 8

2.2 Industries 8

2.3 Occupational classes 11

$\begin{array}{ll}2.4 \text { Academic studies } & 15\end{array}$

3. Replacement demand 20

$\begin{array}{ll}3.1 \text { Introduction } & 20\end{array}$

3.2 Replacement demand by occupational class: 20

3.3 Demand for 'schoolleavers' by occupational class 23

3.4 Replacement demand by university discipline 24

4. The labour-market situation by university discipline 28

5. Some risk indicators 31

5.1 Introduction 31

5.2 Employment fluctuations in occupational classes 31

5.3 Branche dispersion of occupational classes 32

5.4 Occupational spread of university disciplines 34

6. Labour-market prospects 37

$\begin{array}{ll}6.1 \text { Introduction } & 37\end{array}$

6.2 Prospects of occupational classes 37

6.3 Prospects of academic studies 43

7. Conclusion 45

8. Literature 46 



\section{INTRODUCTION}

For the labour market to function properly, young people should consider the situation on the labour market before making educational choices. Which is indeed what in practice they tend to do, as is apparent from various surveys (see, for instance, Kodde 1984 and De Grip 1984). Although they do not seem to maximise their future income, as human-capital theory implies, but primary maximise their chance of a job later-on.

However, for lack of information about the future labour-market situation, youngsters have to go by the situation as they find it at the time they take up their studies. That way, they run the risk of overreacting to existent shortages or surpluses in certain labour-market segments, thus setting so-called 'cobwebs' in motion (see De Grip 1987).

Such overreactions might be tempered if forecasts were available of the labour situation at the moment when those who today have to choose a line of studies will make their entrance on the labour market, as these forecasts take into account the number of future schoolleavers who are now al ready in the 'educational pipeline'.

In the 1960s, labour-market forecasts were all the vogue. They were mostly employment forecasts drawn up by the so-called 'Manpower Requirements Approach' (see, among others, Hollister 1965). That approach comprises the following steps:

(1) a forecast is made of the macro-economic development;

(2) the outcome is used to forecast the development of production by industry;

(3) from the expected development of sectoral labour productivity a forecast is derived of employment in the various industries;

(4) on the assumption of an unchanged occupational structure of the 
industries, employment in the various occupations is estimated;

(5) on the further assumption of an unchanged educational structure of the occupations, finally a forecast can be drawn up of the need for workers by educational levels and branches of study.

The fourth step is often passed over; from the employment forecasts by industry, a direct estimate is drawn up of the need for instruction and training (see Youdi \& Hinchcliffe 1985).

Apart from the uncertainty inherent to macro- and meso-economic forecasts, this approach is criticised most for the mechanical breakdown of employment by industry into occupational and educational groups. In fact, it assumes zero substitutability of workers with different professions and/or education. Moreover, employment in a given profession is translated into the need for schoolleavers with a given kind of schooling on the assumption of a unique relation between the profession and the training needed. Blaug observes in that respect (1967, p. 281): "And here the real problem is not simply the failure to observe any unique relationship between educational background and occupational affiliation in to-day's labour force, except for those professions such as medicine and teaching where custom imposes a minimum entrance qualification, but the difficulty of separating the forces of supply from the forces of demand. What we have here is the old 'identification problem'. After all, the schooling currently associated with each occupation is as much the outcome of the supply of educated people in the past as of the history of the demand for qualified manpower. In any economy with a high level of aggregate demand qualified manpower, however irrationally produced, will somehow be absorbed into employment: what we observe to-day may simply represent the misallocations of the past".

Van Hoof and Dronkers (1980) label the assumed direct relation between a profession and a branch of studies as the 'naive model' of the labour 
market. That in practice the relation between professions and studies is much more flexible, is in their opinion a major reason why so many manpower forecasts are not fulfilled.

A forecast study made by the Netherlands Economic Institute (1986) tried to take account of that criticism by extrapolating both the development of occupational structures of industries and the educational structure of occupations. The underlying assumption is that future developments, among which the adjustment processes on the labour market, will correspond in nature, volume and implications with those of the past.

For a recent CPB forecast of employment by various educational categories (1987), explanatory factors for the shifting educational structures of industries were suggested, in an attempt to produce employment estimates incorporating the ensuing changes. This CPB forecast however distinguishes only four levels of education (primary education, lower vocational and general education, intermediate vocational and general education and higher vocational and academical education) and four branches of study (general, economic/clerical, and service). Obviously, these divisions are far too broad to be useful for educational and vocational choices or educational planning.

The present study sets out to draw up labour-market forecasts for some specific branches of scientific education in our country. Twelve branches of study have been distinguished. Such detailed forecasts run a greater risk of non-fulfilment than less differentiated estimates, in which forecasting errors are more likely to compensate one another, which are apt to overlook future shifts in educational structure within the broad branches of study distinguished. The choice is between between qualitatively better but less detailed forecasts, and forecasts which, while perhaps poorer in quality, are more relevant to educational and vocational choice. To sidestep the dilemma, we have decided to present only qualitative indications of employment prospects (good, bad, etc.) rather than exact figures. 
The ultimate object of the study is to produce forecasts for academic studies. However, to get an overall picture of expected developments, we shall give attention to the underlying forecasts for (a11) 82 occupational categories distinguished.

Additional information is supplied about the employment risks involved in entering an occupation and in following a certain academical study. With respect to occupations, the indicators chosen are the fluctuations of employment and the dispersion of an occupational class among industries. The dispersion indicates to what extent workers can divert to other branches of industry. A similar indicator has been constructed for the occupational spread (indicative of flexibility) of the various study disciplines.

Students have to match their educational choice to the labour market in a situation of uncertainty. Our goal must be to reduce that uncertainty by giving those who have to make a choice the fullest possible information about all relevant factors. With that purpose in mind, we aim to supply those about to take up a study not only with a qualitative forecast of the labour-market situation in five years' time, when they can finish their studies ${ }^{1}$, but also with information about the fan of occupations which the chosen discipline opens to them, the diversions into other industries which an occupation allows, and the cyclical sensitivity of various occupations.

For the time being, the data available are far from complete. The CBS Labour-Force Censuses we have used are available only for the odd years in the 1975-1985 period (data about training and education only from 1979 onward). Moreover the occupational data (two-digit 'occupational classes') are inadequate to support educational and occupational choices ${ }^{2}$.

1. 1992 for those who take up a university study in 1988.

2. De Grip, Groot and Heijke (1987) have attempted to supply a solution for that problem. 
The present report is organised as follows. Chapter 2 deals with employment forecasts, by industry (section 2.2), occupational classes (section 2.3) and branches of studies (section 2.4). Chapter 3 considers the forecasts of replacement demand for the various occupational classes (section 3.2), the demand for schoolleavers by occupational class (section 3.3), and replacement demand by study branch (section 3.4).

Chapter 4 describes the labour-market situation by branches of studies. Attention is given, first, to the demand for newcomers between 1985 and 1992, and next, to the supply of graduates in the same period; finally a typology is presented of the 1992 labour-market situation for the twelve university disciplines distinguished.

Chapter 5 introduces the risk indicators mentioned above. Attention is given, in succession, to employment fluctuations (section 5.2), the dispersion of occupational classes across branches (section 5.3), and the dispersion of occupations among study disciplines (section 5.4 ).

Chapter 6 reviews the labour-market prospects of the occupational classes (section 6.2) and study branches (section 6.3), thus providing the kind of qualitative indication which, as said before, should be supplied to those who are about to embark upon their university studies. If required, these students can use the data material presented in the previous chapters as background information. Chapter 7 completes the paper with some evaluating remarks. 


\section{EMPLOYMENT FORECASTS}

\subsection{Introduction}

This chapter describes how the forecasts of employment by occupational class and study branch in 1992 have been realised. Three steps can be distinguished. First, employment in the various industries was estimated. Next, the sectoral forecasts thus obtained were used as basis for the employment forecasts by occupational class. From these, in turn, were derived the forecasts by study branch. The next three sections deal with these three forecast steps.

\subsection{Industries}

Industrial forecasts represent the first step towards employment forecasts for 1992. We started from the medium-term estimates of the Dutch Central Planning Bureau (CPB 1986). Table 1 shows some assumptions underlying those estimates, most of them referring to the international competitive position of business companies.

Table 1: Assumptions underlying the CPB medium-term forecast

\section{Assumptions}

Volume of world trade (unweighted)

Competing exports

Price level of goods imports (in Dutch guilders)

Price level of exports (in Dutch guilders)

Wage costs by unit of product in processing industry abroad

Effective rate of exchange of the guilder

- in respect of competitors on foreign markets

- in respect of suppliers

Volume of physical government expenditure

Hours per working year

Rate of exchange of the dollar
Average annual percentage mutation Assumptions 1986-90 
The medium-term estimates give forecasts of the labour volume (in manyears) in 23 industries in 1990. For the years 1986 and 1987, these forecasts can be brought up-to-date on the basis of the 1987 Central Economic Plan (CPB 1987). Besides, in consultation with the CPB the assumption has been made that the development of industrial labour volumes in the 1990-1992 period will not diverge from the growth paths foreseen in the medium-term estimates for 1990.

To transform them into a forecast of employed persons, we have raised the labour-volume estimates in accordance with the discrepancies, foreseen in the medium-term estimates for seven main industries, between the development of the labour volume and that of the number of employed persons. As the contraction of working hours and the growth of part-time work seems to be somewhat on the wane just now, we have assumed that the decline of average worktime of a worker as estimated by the CPB for the 1985-1990 period will in fact spread to 1992. In consultation with the $C P B$, two further small corrections have been made in the employment forecasts for banks and insurance companies and for medical and veterinary services.

Table 2 gives a survey of the results of these estimates. The expectation is that total employment will increase by 10 per cent in respect of total employment in 1985. Industries for which more-thanaverage growth is predicted are : other private services, trade, ownership of dwellings, medical and veterinary services, chemicals industry, manufacture of metal products, mining and quarrying, manufacture of transport equipment and other public services. The agricultural sector and the manufacture of wood and building materials and glass products are the only industries for which a decline in the number of employed persons is expected.

These forecasts are based on the estimated changes of the work volume and the expected developments in average work time per employed person. The average work time will drop owing to a further contraction of working hours for full-time workers and the increasing number of part- 
Table 2: Forecast of employed persons by sectors of activity, 1992.

\section{working people $\underline{1992}$}

1. Agriculture, fishing, forestry

2. Manufacture of foodstuffs, beverages, tobacco products

3. Manufacture of textiles, wearing appare1, footwear and other leather products

4. Manufacture of wood and building materials and glass products

5. Manufacture of paper and printing and publishing industries

6. Chemical industry and manufacture of rubber and plastic products

7. Basic metal industries

8. Manufacture of metal products, mechanical and instrument engineering

9. Electrical engineering

10. Manufacture of transport equipment

11. Petroleum industry

12. Mining and quarrying

13. Electricity, gas and water

14. Construction

15. Ownership of dwellings

16. Trade (wholesale and retail

17. Sea- and airtransport

18. Transport, storage and communication

19. Banking and insurances

20. Other private services

21. Medical and veterinary services

22. Public administration and education

23. Other public services

24. Industry unknown
258.900

168.200

$\%$ mutation $\underline{1985-' 92}$

58.400

71.100

124.000

132.000

34.100

287.500

112.800

80.400

9.500

12.900

45.200

393.100

35.800

839.200

56.600

297.100

191.100

676.500

432.500

480.500

822.200

42.500
$-2.5$

8

14

2.5

13

$-3.5$

1.5

5

12

13

0

13

2.5

2

16

16.5

11

9.5

3

20.5

15.5

12.5

5.5

10

Total

5.662 .100 
time workers. Especially the latter factor will considerably push up the number of workers in trade and the public and other non-commercial services.

\subsection{Occupational classes}

To specify the estimates of sectoral employment by 82 occupational classes (ISCO-classification) was the next step. Two hypotheses were adopted. The first is that a given occupational class will penetrate faster into an industry as employment in that inustry grows faster. Or, in reverse, that the share of a given occupational class in industrial employment declines faster as employment in that industry drops more rapidly. This hypothesis might be called the hypothesis of the rate of absorption or expulsion.

The second hypothesis presumes that the share of a given ccupational class grows or declines faster as the production process is influenced more strongly by technological advance; it is called, accordingly, the hypothesis of technological development.

The testing of both hypotheses is meant merely as a first step towards a better theoretical explanation of shifts in the occupational structures of industries. The method improves upon those applied in former studies (NEI 1986, Ministry of Social Affairs and Employment 1987), by which merely trend-wise developments are extrapolated.

The testing of the hypotheses by time-series research is seriously hampered by the fact that the number of employed persons by occupational class is known only from the six labour-force censuses held since 1975. With so few observation years, only a test by simple regression analysis is possible.

Whenever no significant relation could be found between the development of the employment share of an occupational class within an industry and either explanatory variable, we have tried to identify a trend-wise 
development of that employment share. The underlying hypothesis is that a significant trend can serve as a proxy for the working of adjustment mechanisms on the labour market, which are not yet adequately tested by the other explanatory variables used.

Because for each industry the employment forecasts for individual occupational classes must add up to the - presumably given - industrial employment forecasts (see section 3.1.1), we have opted for a distribution model (see also NEI 1986). To that end, we have chosen for each industry a reference occupational class which in the 1975-1985 period held a fairly stable share in industrial employment and was neither too large nor too small. The reference occupations may differ among industries but are always the same within an industry. The following formulation has been chosen for the equations to be estimated ${ }^{3}$ :

(1) $\ln \left(E_{i j} / E_{z j}\right)=\alpha_{i j}+\beta_{i j} X_{j}+u_{i j}$

where: $E_{i j}=$ workers employed in industry $j$ with occupation $i ; E_{z j}=$ workers employed in industry $j$ with reference occupation $z ; X_{j}=$ industry-specific explanatory variable or a trend variable; $\alpha_{i j}, \beta_{i j}=$ regression coefficients; $u_{i j}=$ disturbance term.

In this specification, the development of the employment of occupation $i$ in industry $j$ is set off against the employment development of the reference occupation in the same industry. The coëfficiënts estimated indicate how far the occupational class in question has developed differently from the reference occupation. With exception of the reference occupations, ten different regression equations have been estimated for every occupational class within every industry. Three groups of explanatory variables have been distinguished.

3. To prevent the ratio $E_{j j} / E_{z j}$ from assuming negative values, its logarithm has been taken. 
The first group comprises the explanatory variables formulated from the absorption- or expulsion-rate hypothesis. The explanatory force of this hypothesis is analysed with the help of the industrial employment development, represented by four indicators, each of which can individually function as an explanatory variable, namely: the employment level $\left(E_{j}\right)$, its logarithm $\left(1 n E_{j}\right)$, the absolute mutation of employment between two observation years $\left(\Delta E_{j}\right)$ and the percentage employment mutation $\left(\dot{E}_{j}\right)$. These explanatory variables have been introduced only as far as an industry's employment had developed between 1975 and 1985 in the same sense as forecasted for the 1985-1992 period.

The second cluster of variables represents the hypothesis of technological development. Sectoral labour productivity, its logarithm, and its percentage change serve as proxy variables for the extent to which technological advance brings about the innovation of an industry's production processes.

Where industry-specific variables failed to explain shifts in the industrial occupational structure in spite of an evident pattern of development in the period under investigation, we have also looked for trends in the evolution of the variable to be explained. Therefore, regressions have been carried out with three functions of time: $t, \ln (t)$ and $1 / t$.

From the correlations established by the regression analysis we have derived the shares of the occupational classes in industrial employment in 1992. Four principles have been applied:

1. For an occupational class within an industry to be included in the analysis, a minimum of 500 persons belonging to that occupational class must have been employed within the industry throughout the observation years. That restriction has been adopted because with low absolute numbers margins of unreliability tend to be very wide. 
2. As pointed out before, an industry-specific explanatory variable with significant explanatory power was invariably preferred to any trend variable.

3. Whenever industry-specific variables are significant, the equation with the highest correlation coefficient $\left(R^{2}\right)$ was chosen.

4. When no significant relations were found, we assumed that the (logtransformed) ratio between employment in an occupational class and the number of persons employed in the reference occupation in 1992 equals the average of the 1975-1985 period, unless the ratio evidently changed in that period: in that case the 1992 ratio was taken to be equal to the 1985 ratio.

In a few cases in which the preferred equation led to irrealistic peaks in the forecast, we have slightly relaxed the above decision rules.

In forecasts for 1992 based on the relation found with an sectorspecific explanatory variable, the value of $\ln \left(E_{i j} / E_{z j}\right)$ for 1992 was calculated by completing the equation with the forecast value for the industry-specific variable in 1992. In forecasts based on a significant time variable, the observed trend was extrapolated to 1992 . In the remaining cases, the procedure formulated in the fourth decision rule was adhered to.

With the help of the next formula, the forecast values of $E_{i j} / E_{z j}$ can be transformed to forecasts of employment in the various occupational classes within an industry:

(2) $E_{i j}=\frac{\left(E_{i j} / \hat{E}_{z j}\right)}{1+\sum_{i \neq z}\left(\hat{E}_{i j} / \hat{E}_{z j}\right)} \hat{E}_{j}$ 
Summation over the industries then produces the forecast of total employment in an occupational class in 1992:

(3) $\quad E_{i}=\sum_{j=1}^{23} E_{i j}$

Table 3 shows the ten occupational classes for which the greatest absolute or relative growth in the 1985-1992 period is expected. The greatest absolute employment growth will occur in two relatively lowskilled occupational classes, 'building caretakers, charworkers and cleaners' and shop assistants. Only relatively skilled occupational classes follow.

In relative terms, the occupational class 'mathematicians, system analists and related workers.' is the fastest-growing by far. The fast relative growth of the occupational class 'farm managers and supervisors' does not reflect good employment prospects, but springs merely from a shift in the occupational structure from self-employed to managers in the agricultural sector.

Table 4 displays occupational classes for which employment is expected to decline or stagnate. There is not a single class among them in which a significant number of university graduates are employed.

\subsection{Academic studies}

The next step was to use the employment forecasts by occupational class as the basis for employment forecasts for the twelve disciplines into which we had split university education (see table 5). To the analogy of the previous step in which the occupational structure of industries was determined, we estimated the educational structure of the occupational classes in 1992. 
Table 3: The fastest growing occupations (in absolute and relative terms), 1985-1992

absolute mutation

relative

employment

mutation

$\underline{\%}$

1. Building caretakers charworkers and cleaners

53.000

42.000

1. Mathematicians, systemanalists and related technicians*

2. shop assistants

2. Farm managers and supervisors

3. Medical workers nursing personnel*

38.000

3. Building caretakers, charworkers and cleaners

4. Bookkeepers, cashiers and related workers

35.000

4. Working proprietors hotel and catering services

5. Jurists* related workers*

33.000

31.000

6. Economists*

6. Teachers

7. Accountants* analysts and related technicians* 29.000

8. Precision instrument makers, machinery fitters, machine assemblers and related workers

8. Government executive officials*

22.000

9. Engineers, draughtsmen and related technicians*

10. Secretarians and typists* 20.000

9. Mail distribution clerks 25

10. Working proprietors wholesale trade 25

* Occupational class employing a minimum of 1000 university graduates.

Table 4: Occupational classes with declining or stagnating employment, 1985-1992

absolute mutation employment

-5000
-2000
-1000
-1000
-500
-500
0
0
0
0

relative mutation

1. Farmers

2. Agricultural workers

3. Tailors, dressmakers, sewers and related workers

4. Working proprietors retail trade

5. Spinners, weavers, dyers and related workers

6. Fishermen and related workers

7. Stationary engine and related equipment operators

8. Jewellery and precious metal workers

9. Workers in religion

10. Tobacco product makers
\%

$-8$

$-2$

$-3$

$-1$

$-7$

$-8$ 
The only data available for such a forecast are the results of the four Labour-force Censuses held between 1979 and 1985, as the educational classification which the Central Bureau of Statistics used in 1975 and 1977 is not comparable with the one used later on. Since we were interested only in the development of employment for graduates of university education, there was no need to employ a distribution model; the development of a discipline's share in employment within an occupational class could be established directly.

At this stage of the forecast model, we tried once more to find an explanation for shifts in the share of a given education in the employment of an occupational class. Two processes can in principle be distinguished, 'bumping-down processes' and horizontal substitution. Bumping down processes means that the lower-skilled of a discipline are pushed out of an occupation by the higher skilled of the same discipline (De Grip 1987). Horizontal substitution implies that the share of one discipline in employment grows at the expense of another discipline of the same educational level. To make an employment forecast, the two processes need not be analysed separately.

As in the previous section, we here assume that the shift will be greater as total employment in an occupational class grows faster. Once more an absorption- or expulsion-rate hypothesis applies. For the moment only the 'pull' effects of bumping-down processes or horizontal substitution can be considered, for the few observation years do not permit considering also the 'push' effect of shifts in the educational structure of the labour supply.

To estimate the share of a given branch of study in the employment of an occupational class, the following regression equation serves:

$$
E_{k j} / E_{i}=\theta_{k i}+\psi_{k i} x_{i}+u_{k i}
$$

where: $E_{k j} / E_{k i}=$ the workers with education $k$ employed in occupation $i$; $\theta_{k i}, \psi_{k i}=$ regressions coefficients; $u_{k i}=$ disturbance term. 
For each university discipline represented in an occupational class, five equations have been estimated with respect to the four observation years between 1979 and 1985. The explanatory variables tested in the first two equations are those following from the absorption- or expulsion-rate hypothesis (bumping-down and/or substitution): the employment level in the occupational class $\left(E_{j}\right)$ or its logarithm (1n $\left.E_{j}\right)$.

Whenever these occupation-specific variables could not significantly explain the development of a discipline's share in employment, we tried to establish a trend-wise development of this share with the help of three trend variables: $t$, in $t$, and $1 / t$.

Once more the principle was not to carry out regressions if in a given occupational class in a given year of observation fewer than 500 persons from the branch of study concerned were employed. On this point some exceptions had to be made for types of education which had risen far above 500 persons employed in the course of the 1980's. Here too, the equation with the highest correlation coefficient was invariably chosen.

To forecast a discipline's share in employment in an occupational class in 1992, we either completed the equation with the predicted value of the occupation-specific explanatory variables in 1992, or extrapolated the established trend to 1992. When no significant correlations were found, we assumed that the share of the type of education in 1992 equalled the share of that type in the same occupational class in 1985, an assumption that seemed justified because for most university disciplines (with many observations below 500) the employment share increased between 1979 and 1985. Therefore a forecast of the 1992 share on the basis of the average share in the 1979-1985 period would mistakenly come out lower than the 1985 share.

By multiplying the predicted employment share of a branch of study by the estimated employment in the occupational class concerned, we found the estimated number of persons with that study discipline employed in 
the occupational class in 1992. Summation over all occupational classes produces the forecast of total employment for university graduates of the discipline.

Table 5 shows the employment expectations for 1992 for the various university disciplines. The overall impression is that university graduates will continue to push the lower-educated out of employment. For, while our forecast sets the total growth of employment at some 10 per cent (see table 2), an increase by no less than 27 per cent is expected for the number of university graduates employed.

The fastest relative growth is expected for the disciplines of econometrics, actuary and management (B.SC.) and technical sciences. Only a weak growth of employment, on the contrary, is expected for medical studies, pharmacology, fine arts, language and literature, and theology.

Table 5: Forecasts of employed persons by disciplines of scienctific education, 1992

\begin{tabular}{cc} 
Persons employed & $\%$ mutation \\
1992 & $1985-192$ \\
\hline
\end{tabular}

1. Econometrics, actuary and management (B.SC.)

5.500

62

2. Technical sciences

54.400

46

3. Socio-cultural sciences

51.500

32

4. Law

36.400

31

5. Mathematics and physics

27.600

24

6. Agricultural and domestic

6.700

23

7. Economics and business administration (B.A.)

8. Medical sciences

25.800

22

9. Pharmacology

10. Fine arts

41.800

1.900

15

11. Language and 1iterature

1.800

15

18.600

13

12. Theology

8.300 


\section{REPLACEMENT DEMAND}

\subsection{Introduction}

A forecast of future employment or employment growth is not sufficient for an adequate view of the employment prospects of newcomers to the labour market. It indicates only the number of jobs newly created or disappeared, however newcomers to the labour market may land in functions vacated during the forecast period by those holding them at present.

Therefore, we have also attempted to estimate the expected replacement demand on the labour market from the predicted outflow of workers in the 1985-1992 period. In succession we shall discuss the expected replacement demand by occupational class (section 3.2), the demand for schoolleavers by occupational class (section 3.3), and the replacement demand expected for the different study disciplines (section 3.4).

\subsection{Replacement demand by occupational class}

The outflow of workers in an occupational class can be estimated by subdividing the workers into five-year age cohorts. We have used the available data on the age structure of the working population in 1985 and 1992. The forecast of the age structure comes from the Central Planning Bureau (Op de Beke 1987). On the assumption that the labour force is evenly spread among the year classes of the five-year cohorts, we can establish how many workers of a given age leave or enter the labour force on balance. To that end we compare the number of workers of age $c$ in 1985 with the number of those who by the forecasts will be $c+7$ years old in 1992. On that basis the annual net outflow from the labour force can be calculated for the different age cohorts $\left(9_{85}-92 \mathrm{VBB}_{\mathrm{C}}\right)$.

Obviously, however, the relative outflow varies quite a bit among occupational classes. The occupation-specific component in the outflow 
is corrected for by considering the difference between the annual development in an age cohort in an occupational class and the annual development of the corresponding age group in the total employed population in the 1979-1985 period:

$$
g_{85}-92 V{ } K_{i c}=985-92 V_{B B}-\left(g_{79-85} V P_{c}-g_{79-85} V_{B K} K_{i c}\right)
$$

where : $g V B_{i c}=$ annual net outflow of age $c$ from occupational class $i$; $g \mathrm{VBB}_{\mathrm{C}}=$ the same for the labour force;

$g V W P_{C}=$ the same for the working population.

The assumption is that the annual change of the occupational-class component between 1985 and 1992 is identical to that between 1979 and 1985. By comparing the outflow of employed persons in a occupational class with the outflow from the total working population rather than with the outflow from the labour force, the cyclical component of the outflow (the outflow to unemployment) is prevented from disturbing the picture ${ }^{4}$.

As for calculating replacement demand we only need to know the outflow, we have considered only the cohorts with a positive net outflow (in particular the older age groups). Summation over these age cohorts produces the calculated total replacement demand in the occupational class concerned.

Table 6 presents the ten occupational classes with relatively the highest, and the ten with relatively the lowest expected replacement demand during the 1985-1992 period. The average replacement demand in this period amounts to some 18 per cent of the number of employed persons in 1985. A comparison of this percentage with the expected employment growth of 10 per cent shows how important it is to incorporate replacement demand in employment forecasts.

4. This holds only as far as the relative outflow from an occupational class to unemployment does not deviate from the average. 
Table 6: Occupational classes with the relatively highest and lowest replacement demand, 1985-1992 Absolute replacement
demand in $\%$ of employed

persons, 1985

High replacement demand

1. Spinners, weavers, dyers and related workers

5.300

46

2. Other labourers (porters and related workers)

$18.200 \quad 40$

3. Miners, quarrymen, well drillers and related workers

700

37

4. Cabinetmakers and related woodworkers

6.100

37

5. Production and related workers not elsewhere classified

4.600

35

6. Wood preparation workers and

2.500

7. Bricklayers, carpenters and other construction workers

57.500

8. Plumbers, welders, sheet metal and structural metal preparers and erectors

34.700

9. Managers hotels and catering services

4.300

33

10. Blacksmiths, toolmakers and machine-tool operators

13.100

\section{Low replacement demand**}

1. Broadcasting station and sound equipment operators and cinema projectionists

2. Statisticians, mathematicians, system analysts and related technicians*

1.500

3. Authors, journalists and related writers*

4. Tobacco product makers

6

5. Jurists*

100

1.400

7

6. Managers wholesale trade*

2.300

8

7. Musicians, actors and other performing artists

1.500

8

8. Social workers, translators and related workers*

9.700

9. Biologists and related technicians

2.600

10. Managers retail trade

1.600

* Occupational class employing a minimum of 1000 university graduates.

** A very small occupational class has been left out of account. 
For several, in particular manufacturing, occupational classes the replacement value found is clearly above average. The fact should be considered that in many of these occupational classes employment is stagnating so that the outflow is actually replaced only as far as employment in that occupational class is not declining.

In the occupational classes with a relatively low replacement demand we find various occupations with a relatively young population, among them several occupations employing many university graduates. For several of these occupational classes a relatively favourable development of employment is expected. The makers of tobacco products form an exception.

\subsection{Demand for 'schoolleavers' by occupational class}

Addition of the employment mutation and replacement demand produces total demand for newcomers in an occupational class during the forecast period from 1985 to 1992. A portion of the vacated job opportunities will be filled by workers formerly employed in other occupational classes (occupational mobility) and by re-entrants into the labour force. Given professional mobility and re-entrance, total demand for schoolleavers in an occupational class can be defined as follows:

(6) $\quad D S_{j} \equiv \Delta E_{j}+\left(Q_{j}-R_{j}\right)$

$\begin{array}{rlrl}\text { where: } & D S=\text { demand for schoolleavers; } & R=\text { re-entrance; } \\ E & =\text { mutation of employment; } & & i=\text { occupational class; }\end{array}$

$Q=$ outflow.

The method to calculate net outflow ( $Q$ minus $R$ ) was the same as has been used to compute the replacement demand in an occupational class. In this case, however, we have considered not only the age cohorts for which a positive net outflow has been predicted, but also those with a net reentrance. The assumption is that in the age groups under 30 only schoolleavers enter an occupational class. Of course, in practice this 
is not invariably true. Therefore, whenever there is mention of 'schoolleavers', in fact the inflow prospects of workers under 30 into an occupational class are referred to.

Table 7 gives the occupational classes for which, between 1985 and 1992, the greatest absolute or relative demand for schoolleavers is expected. In absolute terms, many schoolleavers may enter the labour force as shop assistants, clerks, construction workers, and (medical workers and) nurses. In relative terms, the demand for new young workers is greatest in the occupational class of managers of hotels and catering services. Various manufacturing occupations follow. The demand for executive senior civil servants is also striking.

In the occupational classes usually entered at a more advanced age, such as the class of 'managers (private sector)', the net outflow is mostly negative, which means that the demand for schoolleavers in this class may be zero, despite an increase in employment.

Table 8 presents the 23 occupational classes for which no direct inflow of schoolleavers is expected in the 1985-1992 period. The list indicates that, various managerial occupations are not directly open to schoolleavers. Besides, there are some occupational classes in which the poor employment growth is fully absorbed by the inflow of workers from other classes.

\subsection{Replacement demand by university discipline}

To trace replacement demand by discipline the method described in section 3.2 is useless because the occupational mobility of workers would distort the picture. Indeed, part of the outflow from a given occupational class will flow into other occupational classes in which workers tend to arrive at a later stage of their careers. That is why the expected outflow can here only be roughly approximated. To that end, we have considered the workers in an occupational class who are 55 or older in 1985. 
Table 7: Occupational classes with the greatest absolute or relative demand for schoolleavers, 1985-1992

Absolute high demand

\begin{tabular}{l} 
demand for \\
school leavers \\
$1985-\quad 1992$ \\
\hline
\end{tabular}

Relative high demand**

demand for schoolleavers in $\%$ of persons employed in 1985
1. Shop assistants

2. Various clerical and related workers*

3. Bookkeepers, cashiers and related workers*

4. Bricklayers, carpenters and other construction workers

5. Precision instrument makers machinery fitters, machine assemblers and related workers

6. Secretaries and typists

7. Transport equipment operators

8. Material-handling and related equipment operators, dockers and freight handlers

9. Medical workers and nursing personnel*

10. Plumbers, welders, sheet metal and structural preparers and erectors
43.200

86.900

78.200

70.310

60.100

54.900

44.100

40.300

40.300

39.700
1. Managers hotels and catering services

2. Wood preparation workers and paper makers

3. Cabinetmakers and related woodworkers

4. Government executive officials*

5. Spinners, weavers, dyers and related workers 40

6. Plumbers, welders, sheet metal and structural metal preparers and erectors 38

7. Production and related workers not elsewhere classified 38

8. Blacksmiths, toolmakers, and machine-tool operators

9. Bricklayers, carpenters and other construction workers

10. Painters

* Occupational classes in which a minimum of 1000 university graduates are employed

** Occupational classes with a mutation below 1000 have been left out of account 
Table 8: Occupational classes for which no direct inflow of schoolleavers is expected for the 1985-1992 period

- Tanners, fellmongers and pelt dressers

- Broadcasting station and sound equipment operators and cinema projectionists

- Managers whole sale trade*

- Legislative officials and government administrators*

- Managers (private sector)*

- Authors, journalists and related writers*

- Workers in religion*

- Housekeeping and related services supervisors

- Clerical supervisors

- Farmers

- Stone cutters and carvers

- Insurance, real estate, securities and salesmen and auctioneers

- Production and related workers not elsewhere classified

- Musicians, actors and other performing artists

- Fishermen and related workers

- Jurists*

- Transport and communications supervisors

- Mail distribution clerks

- Managers retail trade

- Production supervisors and general foremen

- Rubber and plastic products makers

- Tobacco product makers

- Social workers, translators and related workers*

* Occupational class employing a minimum of 1000 university graduates.

The assumption is that this entire group will leave the labour market between 1985 and 1992, which probably implies a slight overestimation of the mutations in these age cohorts. On the other hand, we have not counted the outflow from the labour force of those who had not reached the age of 55 by 1985. Nor has account been taken of reentering university graduates and employed persons completing a university study ad an advanced age.

Next, we have multiplied the estimated outflow from each occupational class by the 1985 shares of university graduates from each discipline in that occupational class, thus breaking down the total outflows into out- 
flows by discipline ${ }^{5}$. Summation over the occupational classes then produces the calculted total outflow and hence the estimated replacement demand by discipline (VSRK):

(7) $\quad \operatorname{VSR}_{k}=\sum_{i=1}^{m}\left(a_{k j} V B B K_{j}\right)$

Table 9 expresses, for the twelve disciplines examined, the expected replacement demand between 1985 and 1992 as a percentage of the number of employed persons in 1985. By far the highest replacement demand is expected for theology; there is also a relatively great replacement demand for economics and business administration, and law studies. The lowest replacement demand is expected for the medical studies and pharmacology.

Table 9: Replacement demand by university discipline (in percentages of the number of employed in 1985), 1985-1992.

1. Theology

2. Economics and business administration (B.A.) 13

3 Law

4. Technical sciences

Econometrics, actuary and management (B.SC.)

6. Agricultural and domestic sciences Socio-cultural sciences

8. Mathematics and physics Language and literature Fine arts

11. Medical sciences Pharmacology

5. The underlying assumption is that a discipline's share in the older age cohorts is equal to its share in the total number of persons employed in the occupational class, an assumption that is probably untrue in some cases. A distorted picture, more in particular an overestimation of the outflow of higher educated persons, may be the result. 


\section{THE LABOUR-MARKET SITUATION BY UNIVERSITY DISCIPLINE}

This chapter gives a typology of the labour-market situation in 1992 for the twelve university disciplines examined. This typology is based on the expected total demand for newcomers of each discipline on the labour market and the estimated inflow of graduates during the 1985-1992 period.

Adding up the expected employment mutation and the expected replacement demand produces the total need for newcomers on the labour market with a given education (VN). This total demand for new workers must not be confused with total demand for labour at a given moment, a static notion mostly understood to mean total employment at a given moment. Table 10 expresses the total demand for newcomers from the twelve disciplines in percentages of the total number of persons employed in 1985.

To arrive at a typology of the expected labour-market situation in 1992 for the various branches of study, the demand forecasts have to be confronted with a forecast of the expected inflow of graduates in the period 1985-1992. From broad forecasts of the Central Planning Bureau, the "Taakgroep Studentenramingen" (Task Group for the Estimation of Student Numbers) annually publishes a more detailed estimate of the future annual numbers of graduates in academic studies, the so-called WORSA-forecasts (Taakgroep Studentenramingen 1985-I). From these forecasts we have derived our own estimates of the number of graduates in the various disciplines. We have taken the WORSA-forecasts for the academic years $1985 / 8$ - 1991/9, both for old-style studies and for first-stage new-style courses in academic studies, and processed them in two ways. First, the estimates of the individual studies have been distributed among the twelve disciplines distinguished. Second, to make the figures comparable with the demand forecasts we also have considered, for some disciplines, the expected numbers of graduates from some non-university training courses which the International Standard Classification of Ecucation (ISCED) counts to the highest level of education. They are of four different types: Academies of Architec- 
ture (attached to the discipline of technical sciences), advanced vocational training courses concerned with the promotion of personal, social and cultural welfare (attached to socio-cultural sciences), NIVRA-accountancy courses (attached to economic sciences), and State Academies for Visual Arts (attached to fine arts) ${ }^{6}$.

For easier comparison with demand mutations, the number of graduates has each time been expressed in a percentage of the number of persons employed in 1985 (AN).

With the exception of the theological and technical disciplines, the number of graduates in the forecasting period appears to be very high in relation to the number of employed persons (see table 10). The reasonapart from the rising trend in the number of graduates in many disciplines - is the double inflow in the few years when old- and newstyle graduates entered the labour market side by side. Besides, the high unemployment rate in the first half of the 1980 s may have induced many students to take up a university study after their finals from secondary schools and higher vocational schools.

By setting off the calculated total demand for new workers from a study discipline in the 1985-1992 period against the expected inflow of graduates into the labour market in the same period, we get an impression of the labour-market situation in which those graduating in 1992 will find themselves. Table 10 gives the results, approximated by a 'labour-market indicator'. We have preferred broad indications to exact figures because we do not feel justified deriving a quantitative forecast of expected unemployment in the forecast year from supply and demand forecasts. For one thing because the estimates of replacement

6. Data for the former two types of training derive from the so-called RHOBOS-forecasts of Higher Vocational Education (Taakgroep studentenramingen 1986-II). The NIVRA-data on the other hand we have established by extrapolating the trend found for the past; the figures of the State Visual-Art Academies are based on information supplied by the Academies themselves. 
demand for the separate disciplines are no more than indicative, and for another because our forecasts of employment developments for university graduates probably do not take sufficient account of the bumping-down processes that are inevitable when the graduates of the 1985-1992 period in their greater-than-ever numbers are entering the market in search of a job (see also section 2.4). Nevertheless we believe that the indicator we have computed, namely, the ratio between the inflow of graduates and the expansion and replacement demand in the 1985-1992 period, gives a reasonably accurate impression of the situation on the labour market in 1992.

Table 10: Typology of labour-market situation by discipline, 1985-1992

$\begin{array}{ll}\dot{V N} & \text { Labour market } \\ \text { (1) } & \text { (2) }(2):(1)\end{array}$

1. Theology

2. Technical sciences

3. Econometrics, actuary

4. Medical sciences

5. Law

6. Socio-cultural sciences

7. Mathematics and physics

8. Economics and business administration (B.A.)

9. Agricultural sciences and domestic sciences

10. Language and literature

11. Pharmacology

12. Fine arts

\footnotetext{
$\dot{V N}=$ demand for newcomers in percentage of the 1985 number of employed persons. $\begin{aligned} \dot{A N}= & \text { number of graduates in percentage of the } \\ & 1985 \text { numbers of employed persons. }\end{aligned}$
}

From the figures of table 10, only for the disciplines theology and technical sciences the labour-market indicator is lower than 1. By contrast, language and literature, pharmacology and fine arts show very high ratios between the expected inflow of graduates and the demand for newcomers. 



\section{SOME RISK INDICATORS}

\subsection{Introduction}

As already pointed out in the first chapter, the adjustment of educational choices to the labour market is surrounded by uncertainty. Forecasts of the labour-market situation at the moment of graduation may eliminate part of that uncertainty. However, these forecasts only indicate the chance students have on finding a first job with the study chosen. To be sure of continuous employment at later stages of their career, they also need to know how employment in their first occupational group will develop in later years, and whether the chosen study opens sufficient lanes to other occupations.

With that in mind we have computed indicators of the fluctuations of employment in the occupational classes distinguished (section 5.2), of the possibility of finding the same kind of occupation in other industries (branch dispersion) (section 5.3), and analogously, of alternative occupations to fall back on with the same educational background (vocational dispersion) (section 5.4 ).

As well as informing students of employment prospects after 1992, these indicators also suggest how far the expectations for 1992 may be upset by unforeseen fluctuations in employment development, and what possibilities individual workers have of migrating to other industries or occupations.

\subsection{Employment fluctuations in occupational classes}

The stable growth of employment evolution in a given occupation may be upset either by structural decline or by cyclical fluctuations. To size up the influence of in particular cyclical fluctuations of employment, we have constructed a fluctuation index (of employment) for the occupational classes distinguished. Following the example of a study by the Netherlands Economic Institute (1972), first a fluctuation index 
was calculated for 23 industries to cover the period from 1950 to 1985. The computation ran as follows:

$$
F I_{j}=\frac{100}{h} \sum_{t=1}^{h} \frac{\left|F_{j t}\right|}{T_{j t}}
$$

where $F I_{j}=$ fluctuation index of industry $j ; h=$ number of observation years; $t=$ year; $F_{j}=$ deviation from trend-wise employment development in branch $j ; T_{j}=$ trend-wise employment development of branch $j$.

Next, the fluctuation indices of all branches were weighted with each occupational class's share in the employment of the branches of activity;

$$
F I_{j}=\sum_{j=1}^{n} a_{i j} F I_{j}
$$

where $F I_{j}=$ fluctuation index of occupational class $i ; a_{i j}=$ share of occupational class $i$ in the employment of industry $j$.

This method of computing implies equal fluctuations of the employment rates of all occupations within an industry (which, of course, is not always so in practice).

Table 11 presents the ten occupational classes with the largest and the ten with the smallest employment fluctuations.

\subsection{Branch dispersion of occupational classes}

When a given occupation is highly concentrated in a limited number of industries, the evolution of employment in that occupation will largely depend on the ups and downs of those branches. A good example is given by the occupational class of teachers, of whom 96 per cent are employed in the public (educational) services. When employment stagnates in that industry, there are not many alternative occupations in other industries. 
Table 11: Occupational classes with the largest and smallest employment fluctuations, 1950-1985

\section{Largest employment fluctuations}

1. Miners, quarrymen, well drillers and related workers

2. Spinners, weavers, dyers and related workers

3. Shoemakers and leather goods makers

4. Tailors, dressmakers, sewers and related workers

5. Tanners, fellmongers and pelt dressers

6. Rubber and plastic products makers

7. Bricklayers, carpenters and other construction workers

8. Stonecutters and carvers

9. Metal processers

10. Chemical processers and related workers

Smallest employment fluctuations

1. Transport conductors

2. Senior civil servants*

3. Teachers*

4. Legislative officials and government administrators*

5. Mail distribution clerks

6. Protective sevice workers

7. Managers hotel and catering services

8. Jurists*

9. Accountants*

10. Heardressers, barbers, beauticians and related workers

* Occupational classes in which a minimum of 1000 university graduates are employed.

Warnken (1986) constructed an indicator to measure the concentration of an occupational class in a limited number of industries; it is called the indicator of an occupational group's branch dispersion. This socalled Gini-Hirschman coefficient is computed in the following manner:

$$
\mathrm{GH}_{i}=\left(1-\sum_{j=1}^{n} \mathrm{~b}_{i j}{ }^{2}\right) \frac{n}{n-1}
$$

where: $\mathrm{GH}_{j}=$ Gini-Hirschman coefficient of occupational class $i ; b_{i j}=$ share of occupational class $i$ in industry $j ; n=$ number of industries. 
In this indicator, the term $n /(n-1)$ corrects for the number of branches considered. In our case, the dispersion across 54 branches has been analysed for all occupational classes.

The value of this indicator varies between 0 and 1 . At a value of 0 the occupation is entirely concentrated in one branch. A value of 1 , on the contrary, indicates a perfectly even spread across the branches.

Table 12 shows the occupational classes with the widest and with the most limited branch spread in the 1979-1985 period. In particular for managerial and clerical occupations the spread is wide. Occupational classes with a narrow spread across branches mostly carry an industryspecific name.

\subsection{Occupational spread of university disciplines}

Similarly to the branch dispersion of an occupational class, the occupational dispersion of the various disciplines of study can be established. 83 occupational classes have been distinguished.

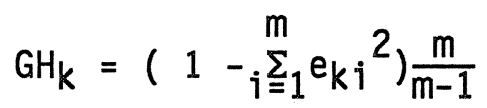

where: $\mathrm{GH}_{k}=$ Gini-Hirschmann coefficient of discipline $k$; $e_{k j}=$ share of discipline $k$ in occupational class $i ; m=$ number of occupational classes.

At a value of 0 a discipline trains only for a single occupational class. A value of 1 indicates a perfectly even spread of occupations.

This indicator of occupational spread indicates the labour-market flexibility of a given discipline, in other words: the number of avenues open to students who have successfully completed their studies. Table 13 gives an impression of the alternatives open to the various disciplines. Most disciplines appear to serve quite a wide range of occupations. Only 
the medical studies have a rather direct association with one occupational class. Keep in mind that the wide definition of the disciplines may in some cases lead us to overestimate the flexibility potential of one specific subject of studies. 
Table 12: Occupational classes with the widest and narrowest branch dispersion, average of 1979-1985

Widest branch dispersion

$\underline{\mathrm{GH}}_{\mathbf{i}}$

1. Managers (private sector)*

0.99

2. Secretarians and typists*

0.94

3. Various clerical and related workers*

0.94

4. Production supervisors and general foremen

0.94

5. Material-handling and related equipment operators dockers and freight handlers

0.94

6. Telephone and telgraph operators

0.94

7. Transport and communications supervisors

0.93

8. Computing and machine operators

0.93

9. Precision instrument makers, machinery fitters, machine assemblers and related workers

10. Engineers, draughtsmen, and related technicians*

0.92

Narrowest branch dispersion

1. Farmers

0.00

2. Working propietors retail trade

0.01

3. Working proprietors hotel and catering services

0.02

4. Managers wholesale trade*

0.02

5. Tobacco product makers

0.02

6. Working proprietors wholesale trade

0.03

7. Stone cutters and carvers

0.03

8. Managers retail trade

0.04

9. Heardressers, barbers, beauticians and related workers

0.07

10. Legislative officials and government administrators*

0.09

* Occupational classes in which a minimum of 1000 university graduates are employed.

Table 13: Occupational spread of academic studies (1979-1985 average)

$\underline{\mathrm{GH}}_{\mathrm{K}}$

1. Economics and business administration (B.A.) 0.86

2. Agricultural sciences and domestic sciences 0.82

3. Mathematics and physics 0.81

4. Econometrics, actuary and management (B.SC.) 0.80

$\begin{array}{ll}\text { 5. Fine arts } & 0.79\end{array}$

6. Law

7. Technical sciences

0.70

8. Socio-cultural sciences $\quad 0.66$

9. Language and literature 0.53

10. Pharmacology 0.51

11. Theology 0.49

12. Medical sciences $\quad 0.22$ 


\section{LABOUR-MARKET PROSPECTS}

\subsection{Introduction}

In chapters 3 and 4 of this study, the employment and replacement-demand forecasts were expressed in percentages of the number of employed persons in 1985. In view of the uncertainty inherent to such forecasts, we do not think it wise to base educational and occupational choices on the exact quantitative estimates. To use them as a basis for a qualitative appreciation of the employment prospects offered by different occupational classes and studies is much more sensible; the more exact prediction outcomes can then be kept available as background information for those interested. In the same vein, the risk indicators discussed in the previous chapter will be transformed into a qualitative typology. Section 6.2 presents the typology of the occupational classes, section 6.3 that of the twelve university disciplines.

\subsection{Prospects of occupational classes}

Forecasts of the labour supply by occupation are not available, only forecasts of the total demand for newcomers on the labour market and the demand for schoolleavers during the 1985-1992 period. For our typology of employment prospects in the various occupational classes we will base ourselves on the former criterion, indicating moreover which occupational classes are not at once accessible to schoolleavers (see table 8). We also apply the indicators of employment fluctuations and branch dispersion. The occupational classes have been classified as follows:

Demand for newcomers (VN)

Vं > $32 \%$ good employment prospects

$24 \leq V \dot{N}<32 \%$ reasonable employment prospects

$18 \leq \mathrm{VN}<24 \%$ moderate employment prospects

VN $<18 \%$ poor employment prospects 
Employment fluctuations (FI)

FI $\geq 15 \%$ very sensitive to business cycle

FI $<15 \%$ little sensitive to business cycle

Branch dispersion (GH)

$0.3<\mathrm{GH} \leq 0.3 \quad$ alternatives available

$\mathrm{GH} \leq 0.3 \quad$ poor alternative possibilities

List I shows the complete typology of the 82 occupational classes. 30 occupational classes offer adequate labour-market prospects, 16 of which are moreover little sensitive to the business cycle; there are also prospects of migrating to other sectors. 10 occupational classes have good medium-term prospects but are highly sensitive to the business cycle. On the other hand, 13 occupations offer moderate and 8 poor labour-market perspectives. Among the occupations with moderate prospects there are some high-skilled public sector occupations, but also the class of managers (private sector). 
List 1: Typology of the prospects of occupational classes

1. Good employment prospects, little sensitive to business cycle, alternatives.

Mathematicians, system analysts and related technicians*

Economists*

Accountants*

Jurists* (NS)

Secretarians and typists*

Computing machine operators

Mail distribution clerks

Telephone and telegraph operators

Sales supervisors and buyers

Shop assistants

Commercial travellers

Working proprietors hotel and catering services

Building caretakers, charworkers and cleaners

Service workers not elsewhere classified

Farm managers and supervisors (NS)

Precision instrument makers, machinery fitters, machine assemblers and related workers

2. Good employment prospects, little sensitive to business cycle, but few alternatives.

Legislative officials and government administrators* (NS)

Government executive officials*

Transport conductors

Working proprietors wholesale trade

3. Good employment prospects, but highly sensitive to business cycle. Alternatives available.

Miners, quarrymen, well drillers and related workers

Wood preparation workers and paper makers

Chemical processors and related workers

Spinners, weavers, dyers and related workers

Cabinetmakers and related woodworkers

Blacksmiths, toolmakers and machine-tool operators

Plumbers, welders, sheet metal and structural metal preparers

and erectors

Rubber and plastic product makers (NS)

Painters

Production and related workers not elsewhere classified (NS)

Bricklayers, carpenters and other construction workers

Other labourers (porters and related workers) 
4. Good employment prospects, but highly sensitive to business cycle, and few alternatives.

\section{none}

5. Reasonable employment prospects, little sensitive to business cycle, alternatives available.

Physical scientists and related technicians*

Engineers, draughtsmen and related technicians*

Biologists and related technicians

Medical workers and nursing personnel*

Sculptors, painters, photographers and related creative artists

Clericial supervisors (NS)

Bookkeepers, cashiers and related workers*

Transport and communications supervisors (NS)

Various clerical and related workers*

Housekeeping and related services supervisors (NS)

Cooks, waiters, bartenders and related workers

Protective service workers

Forestry workers

Stationary engine and related equipment operators

Material-handling and related equipment operators, dockers and

freight handlers

Transport equipment operators

6. Reasonable employment prospects, little sensitive to business

cycle, but few alternatives.

Managers wholesale trade* (NS)

Managers retail trade (NS)

Managers hotel and catering services

Heardressers, barbers, beauticians and related workers

7. Reasonable employment prospects, but highly sensitive to business cycle. There are alternatives, however.

Metal processors

Tanners, fellmongers and pelt dressers (NS)

Shoemakers and leather goods makers

Electrical and electronics workers

Glass formers, potters and related workers

rinters and related workers

8. Reasonable employment prospects, but highly sensitive to business cycle and few alternatives.

none 
9. Moderate employment prospects, little sensitive to business cycle; there are alternatives.

Authors, journalists and related writers* (NS)

Social workers, translators and related workers*

Managers (private sector)* (NS)

Insurance, real estate and securities salesmen and auctioneers

Housekeeping service workers

Food and beverage processors

Broadcasting station and sound equipment operators and cinema projectionists (NS)

10. Moderate employment prospects, little sensitive to business cycle, but few alternatives.

Teachers*

Working proprietors retail trade

Agricultural workers

11. Moderate employment prospects, moreover highly sensitive to business cycle. Alternatives available, however.

Sales workers not el sewhere classified

Production supervisors and general foremen

Tailors, dressmakers, sewers and related workers

12. Moderate employment prospects, moreover highly sensitive to business cycle, and few alternatives.

None

13. Poor employment prospects, little sensitive to business cycle; alternatives available.

Aircraft and ships' officers

Musicians, actors and other performing artists

Jewellery and precious metal workers 
14. Poor employment prospects, little sensitive to business cycle; but few alternatives.

Workers in religion* (NS)

Farmers

Fishermen and related workers (NS)

Tobacco product makers (NS)

15. Poor employment prospects, moreover highly sensitive to business cycle. There are alternatives, however.

None

16. Poor employment prospects, moreover highly sensitive to business cycle, and few alternatives.

Stone cutters and carvers

Paper and paperboard product makers

(NS) $=$ no direct inflow of schoolleavers expected.

* = Occupational classes in which a minimum of 1000 university graduates are employed 


\subsection{Prospects of academic studies}

For the 12 academic studies examined, the forecasts of total demand for newcomers can be combined with the forecasts of the inflow of graduates in the 1985-1992 period. That exercise leads to the labour-market prospects for the various study branches derived in section 4.1 . Besides, the occupational spread of the disciplines will be considered. The typology of the university disciplines is based on the following classification:

\section{Labour-market indicator (AMI)}

AMI $\leq 1$ good labour-market prospects

$1<\mathrm{AMI} \leq 2$ reasonable labour-market prospects

$2<$ AMI $\leq 4$ moderate labour-market prospects

$4<A M I \leq 8$ poor labour-market prospects

AMI $>8$ very poor labour-market prospects

\section{Occupational spread (GH)}

$0.7 \leq \mathrm{GH} \leq 1.0 \quad$ many alternatives

$0.3<\mathrm{GH}<0.7 \quad$ some alternatives

$\mathrm{GH} \leq 0.3 \quad$ few alternatives

List II surveys the typology of the study disciplines distinguished. Only for theological and technical studies the labour-market forecasts are favourable. With respect to theology that is all the more striking as the occupational class "workers in religion", in which many graduate theologists end up, holds out no promise of growth. This discrepancy is caused by two factors. First, replacement demand is very high for theology, and second, in this profession, the inflow of graduates into the labour force is relatively smal1. These factors indicate the inadequacy of labour-market forecasts exclusively based on employment forecasts.

For most branches of study, the medium-term labour-market prospects are not encouraging, although employment for university graduates is expec- 
ted to grow by 27 per cent as compared to a 10-percent growth of total employment. These poor prospects are due to the flooding of the labour market with graduates from most disciplines. That is partly the result of the double outflow of old- and new-style graduates at the beginning of the observation period. Apart from that, the proportion of young people going to university is persistently growing, a tendency that has perhaps been strengthened by the discouraging labour-market situation of the 1980s. Only the disciplines theology, technical sciences and medical studies produce a slightly lesser outflow of graduates to the labour market.

With the exception of medical studies, most disciplines leave scope for wandering to alternative occupational classes. Probably, graduates will have more recourse to alternatives than our estimates foresee if unemployment runs high among them. That these alternatives need have no direct association with the studies followed is demonstrated most clearly by graduates of fine arts studies, many of whom end up in jobs that have nothing to do with arts or teaching.

List II: Typology of the prospects of university disciplines

Discipline

- Theology

Technical Sciences

- Econometrics, actuary and management(B.SC.)

- Legal studies Mathematics and physics Economic sciences and business administration (B.A.)

- Socio-cultural sciences

- Medical studies

- Agricultural studies

- Language and literature Pharmacology

- Fine arts
Typology

Good labour-market prospects and some alternatives

Reasonable labour-market prospects and many alternatives

Moderate labour-market prospects, many alternatives

Moderate labour-market prospects with some alternatives

moderate labour-market prospects, few alternatives

Poor labour-market prospects, with many alternatives

Poor labour-market prospects with some alternatives

Very poor labour-market prospects with many alternatives 


\section{CONCLUSION}

As already pointed out in the Acknowledgement, this working paper is meant to be a first version of the information system about the educational labour market being developed by the Research Centre for Education and Labour Market. Regrettably, the occupational classes and branches of studies for which, for reasons of data availability, we had to draw up our forecasts differ from the actual labour-market segments corresponding to occupations and types of training. The problem can only be solved satisfactorily by using an aggregation of occupations different from the Central Bureau of Statistics classification, and disaggregating the study disciplines further than possible at present.

Evidently, the macro- and meso-economic forecasts underlying our occupational and educational forecasts are an important possible source of uncertainty, for these economic forecasts are necessarily based on several assumptions, in particular with respect to the development of the international competitive position of Dutch industry.

The distribution models at the base of the forecasts for occupational classes and university disciplines are, in contrast to earlier forecast studies, theoretically underpinned by two hypotheses, on respectively bumping-down and upgrading processes. Regrettably, with regard to the bumping-down processes the push effect of shifts in the educational structure of the labour supply could not yet be taken into account. As a result, our forecasts of the labour-market situation by discipline do not pay enough heed to the substitution processes which the soaring number of graduates in several university disciplines is bound to cause. That is one reason why we have refrained from making a forecast of future unemployment percentages in the study disciplines distinguished. That does not mean, however, that the labour-market prospects in most disciplines will be rosier than envisaged in this study. For many disciplines, the absorption of university graduates into the labour market will probably not occur without problems (see List II). 



\section{Literature}

Beke, J.M.J. op de, (1987), Herziening trendmatig arbeidsaanbod 19852000, interne notitie CPB no II.10, 's Gravenhage.

Blaug, M.., (1967), Approaches to Educational Planning, Economic Journal, p. 262-287.

Centraal Planbureau, (1986), Centraal Economisch Plan 1986, Staatsuitgeverij, 's-Gravenhage.

Centraal Planbureau, (1987-I), Centraal Economisch Plan 1987, Staatsuitgeverij, 's-Gravenhage.

Centraal Planbureau, (1987-II), De arbeidsmarkt naar opleidingscategorie 1975-2000, W17, 's-Gravenhage

Grip, A. de, (1984), Arbeidsmarktverwachtingen en de keuze voor de economiestudie, Economisch Statische Berichten, p. 1094-1101.

Grip, A. de, (1987), Onderwijs en Arbeidsmarkt: Scholingsdiscrepanties, vU-uitgeverij, Amsterdam.

Grip, A. de, L.F.M. Groot en J.A.M. Heijke, (1987), Clustering Occupational Classes by Educational Structure, ROA-W-1987/2E, Maastricht.

Grip, A. de, J.A.M. Heijke, R.J.P. Dekker, L.F.M. Groot en L.A. Vos, (1987), De arbeidmarktperspectieven van studierichtingen in het Wetenschappelijk Onderwijs 1992, - Arbeidsmarktmodule I-SEE project, ROAR-1987/3, Maastricht.

Hollister, R.G., (1965), A Technical Evaluation of the First Stage of the Mediterranean Regional Project, OECD, Paris.

Hoof, J.J. van, J. Dronkers (1980), Onderwijs en arbeidsmarkt; een verkenning van de relaties tussen onderwijs, arbeidsmarkt en arbeidssysteem, Van Loghum Slaterus, Deventer. 
Kodde, D.A., (1984), Wie kiest er voor hoger onderwijs?, Tussenverslag van het project "de vraag naar hoger onderwijs", Katholieke Universiteit Nijmegen, RM17 8401, Nijmegen.

Ministerie van Sociale Zaken en Werkgelegenheid, (1987), Rapportage arbeidsmarkt 1987, 's-Gravenhage.

Nederlands Economisch Instituut, (1972), Bouwnijverheid: planning, groei en fluctuaties, deel II: fluctuaties, Rotterdam.

Nederlands Economisch Instituut, (1986), Een verkenning van de arbeidsmarkt naar beroep en opleiding tot 1990, OSA-werkdocument $\mathrm{nr}$. W17, 's-Gravenhage.

ROA, (1987), Naar een informatiesysteem onderwijs-arbeidsmarkt, onderzoekprogramma 1987/1988, ROA-R-1987/2, Maastricht.

Taakgroep Studentenramingen, (1986-I), Wetenschappelijk Onderwijs Ramingen Studenten Aantallen 1986-2000 (WORSA), 's-Gravenhage.

Taakgroep Studentenramingen (1986-II), Raming Hoger Beroepsonderwijs Studentenaantallen 1986-2000 (RHOBOS), 's-Gravenhage.

Warnken, J.,(1986), Zur Entwickelung der "Internen" Anpassungfähigkeit der Berufe bis zum Jahre 2000. Projektionen unter den Annahmen der Wachstumzenarien der Prognos-Studie, Mitteilungen aus der Arbeitsmarktund Berufsforschung, no 1, blz. 119-133.

Youdi, J., K. Hinchcliffe (eds.), (1985), Forecasting Skilled Manpower Requirements: The Experience of Eleven Countries, UNESCO, Paris. 